\title{
ANTIMICROBIAL ACTIVITY AND PHYLOGENETIC ANALYSIS OF STREPTOMYCES PARVULUS DOSMB-D105 ISOLATED FROM THE MANGROVE SEDIMENTS OF ANDAMAN ISLANDS
}

\author{
R. BASKARAN ${ }^{1 *}$, P. M. MOHAN ${ }^{1}$, K. SIVAKUMAR ${ }^{2}$, ASHOK KUMAR $^{3}$ \\ ${ }^{1}$ Department of Ocean Studies and Marine Biology, Pondicherry University, \\ Brookshabad Campus, Port Blair-744 112, Andaman Island, India \\ ${ }^{2}$ CAS in Marin Biology, Annamalai University, Parangipattai, Tamil Nadu-608 502, India \\ ${ }^{3}$ Department of Biotechnology, Himachal Pradesh University, Summer Hill, \\ Shimla, India-171 005
}

(Received 30 June 2015; accepted: 10 December 2015)

Actinomycetes, especially species of Streptomyces are prolific producers of pharmacologically significant compounds accounting for about $70 \%$ of the naturally derived antibiotics that are presently in clinical use. In this study, we used five solvents to extract the secondary metabolites from marine Streptomyces parvulus DOSMB-D105, which was isolated from the mangrove sediments of the South Andaman Islands. Among them, ethyl acetate crude extract showed maximum activity against 11 pathogenic bacteria and six fungi. Presence of bioactive compounds in the ethyl acetate extract was determined using GC-MS and the compounds detected in the ethyl acetate extract were matched with the National Institute of Standards and Technology (NIST) library. Totally eight compounds were identified and the prevalent compounds were 2 steroids, 2 alkaloids, 2 plasticizers, 1 phenolic and 1 alkane. Present study revealed that $S$. parvulus DOSMB-D105 is a promising species for the isolation of valuable bioactive compounds to combat pathogenic microbes.

Keywords: antimicrobial activity, bioactive compound, actinobacteria, Streptomyces parvulus, Andaman Islands

\section{Introduction}

Status of marine sources for unearthing the novel natural products with pharmaceutical potential has been brought out during the last decade and high-

*Corresponding author; E-mail: sivan.thamilan@gmail.com 
lighted in various research articles [1-2]. Microorganisms of different marine environments have been found to produce pharmacologically significant secondary metabolites which are commercially explored for drug discovery. Among the microbes, actinobacteria, with an array of enzymes, yield a broad range of bioactive metabolites of industrial and medical importance. They are one of the most vital sources for new bioactive compounds such as antibiotics and enzymes $[3,4]$. The isolated compounds from the marine actinobacteria have shown a broad spectrum of biological activities, viz. antibiotic, antifungal, toxic, cytotoxic, neurotoxic, antimitotic, antiviral and antineoplastic activities [5]. For many of the marine actinobacteria, taxonomy of the strain is poorly defined so that binomial identification is frequently uneasy to carry out [6].

Streptomyces is the principal genus of actinobacteria [7] and it has been now documented that over $55 \%$ of the antibiotics discovered from the genus Streptomyces represent a total of more than 5000 compounds [8]. However, this genus has been frequently isolated from marine samples such as decaying materials, sediments and animals, numerous attempts have been made to evaluate its antagonistic properties. S. parvulus, isolated from the terrestrial and marine environment, is having potential bioactive compounds, which are available in the market, e.g. Actinomycin D and Manumycin A [9]. Marine soils of India especially those of the Andaman and Nicobar Islands have rich microbial diversity, including actinobacteria. However, they have not been fully explored for microbial resources and their bioactive compounds.

\section{Materials and Methods}

\section{Isolation of Streptomyces}

Sediment samples were collected from the mangrove environment of Burmanallah, South Andamans and were subjected to pre-heat treatment and the pre-treated sediments were used for the isolation of Streptomycetes [10].

\section{Taxonomy of strain DOSMB-D105}

Colour of the matured aerial spore and substrate mycelium and melanin production were recorded in yeast malt extract agar (ISP2), oat meal agar (ISP3), inorganic salt starch casein agar (ISP4), glycerol asparagine agar (ISP5), tyrosine agar (ISP7) and Kuster's agar (KU) [11]. Spore bearing hyphae and spore chain were studied by the direct examination of the cultures under a microscope 
(400 $\times$ magnifications). Spore morphology and mycelial structure were observed in 14 days old culture under scanning electron microscope [12]. Biochemical characterization of the isolate was also made by the methods of Shirling and Gottlieb [11]. Stability of growth in various $\mathrm{pH}$, temperature, carbon and nitrogen sources were also studied. Further, analyses of cell wall amino acids [13] and whole cell sugars [14] were carried out.

\section{Molecular characterization}

Chromosomal DNA was isolated using the previously described method of Wilson and Brent [15]. The template DNA was amplified by using upstream primer (100 pmols) (5'-AGAGTTTGATCCTGGCTCAG 3'), $1 \mu \mathrm{L}$ of downstream primer (100 pmols) (5'-CCGTACTCCCCAGGCGGGG 3') in PCR thermal cycler. The amplification was carried out in the following manner of 35 cycles, denaturation for $60 \mathrm{sec}$ at $92{ }^{\circ} \mathrm{C}$, primer annealing for 60 seconds at $54{ }^{\circ} \mathrm{C}$ and polymerization for $90 \mathrm{sec}$ at $72{ }^{\circ} \mathrm{C}$. Ten $\mu \mathrm{L}$ of PCR products with $2 \mu \mathrm{L}$ of loading dye was analysed by electrophoresis on agarose gel [16]. Retrieved gene sequences were compared with other bacterial sequences by using NCBI BLAST search for their pair wise identities. Multiple sequencing alignments and the phylogenetic tree construction were done with MEGA 4.1 software by using the neighbour joining (NJ) method with 1000 replicates as bootstrap value and $\mathrm{NJ}$ belongs to the distance-matrix method [17]. The 16S rRNA sequence was submitted to the GenBank. The 16S rRNA secondary structure prediction and restriction site of the isolate were analysed by Genebee and NEB cutter program version 2.0 online software (www.genebee.msu.su/services/rna2-reduced.htmlandwww. neb.com/NEBCutter2/index.php) respectively.

\section{Extraction of bioactive compounds}

S. parvulus DOSMB-D105 was cultivated in a 5 L-flask comprising $2.5 \mathrm{~L}$ of production media broth (dextrose $-20 \mathrm{~g}$, soya bean $-20 \mathrm{~g}$, soluble starch $5 \mathrm{~g}$, peptone $-5 \mathrm{~g},\left(\mathrm{NH}_{4}\right)_{2}-\mathrm{SO}_{4}-2.5 \mathrm{~g}, \mathrm{Mg} \mathrm{SO}_{4} 7 \mathrm{H}_{2} \mathrm{O}-0.25 \mathrm{~g}, \mathrm{~K} 2 \mathrm{HPO}_{4}$ $-0.02 \mathrm{~g}, \mathrm{NaCl}-4 \mathrm{~g}, \mathrm{CaCo}_{3}-2 \mathrm{~g}$, seawater $-500 \mathrm{~mL}, \mathrm{dH}_{2} \mathrm{O}-500 \mathrm{ml}$ and $\mathrm{pH}-$ $7 \pm 0.2)$ with shaking at $28 \pm 2{ }^{\circ} \mathrm{C}$ and $250 \mathrm{rpm}$ for seven days. The fermented broth was centrifuged at $10000 \mathrm{rpm}$ at $4{ }^{\circ} \mathrm{C}$ for $20 \mathrm{~min}$ and the supernatants were filtered using $0.45-\mu \mathrm{m}$-spore size membrane filter (Millipore). An equal volume (1:1) of ethyl acetate, methanol, chloroform, hexane, water and alcohol was added separately to the cell free culture filtrates and shaken for $12 \mathrm{~h}$ and the solvent 
extracts were evaporated by rotary evaporator and the crude powder was collected and $20 \mu \mathrm{g}$ was mixed with DMSO to check the activity against eleven bacteria (Muller Hinton agar) and six fungi (Sabouraud's dextrose agar) using agar well diffusion method [18].

\section{GC-MS analysis}

GC-MS analysis of ethyl acetate extract was performed using a PerkinElmer GC clauses 500 system and gas chromatograph interfaced to a mass spectrometer (GC-MS) equipped with an Elite-5 ms, fused silica capillary column (30 $\mathrm{m} \times 0.25 \mathrm{~mm}$ ID $\times 0.25 \mathrm{mdf})$, composed of $100 \%$ dimethyl poly siloxane. For GC-MS detection, an electron ionization system with ionizing energy of $70 \mathrm{eV}$ was used. Helium gas $(99.999 \%)$ was used as the carrier gas at a constant flow rate of $1 \mathrm{ml} / \mathrm{min}$ and an injection volume of $3 \mu \mathrm{L}$ was employed split ratio of 10:1 injector temperature $250{ }^{\circ} \mathrm{C}$; ion-source temperature $280{ }^{\circ} \mathrm{C}$. The oven temperature was programmed from $110{ }^{\circ} \mathrm{C}$ (isothermal for $2 \mathrm{~min}$ ) with an increase of $10{ }^{\circ} \mathrm{C} / \mathrm{min}$-No hold, then $50^{\circ} \mathrm{C} / \mathrm{min}$ to $280^{\circ} \mathrm{C}$, ending with a $9 \mathrm{~min}$ isothermal at $280{ }^{\circ} \mathrm{C}$. Mass spectra were taken at $70 \mathrm{eV}$; a scan interval of 0.5 seconds and fragments from 45 to $450 \mathrm{Da}$. The relative \% amount of each component was calculated by comparing its average peak area to the total areas and the software used to handle the mass spectra and chromatograms was Turbomass. Interpretation of the mass spectrum GC-MS was made using the database of the National Institute Standard and Technology (NIST) having more than 62,000 patterns. Spectrum of the compounds were compared with the spectrum of the known compounds stored in the NIST library. Name, molecular weight and structure of the compounds of the test material were also ascertained.

\section{Results}

\section{Morphological and cultural characteristics}

The isolate DOSMB-D105 was identified by morphological, cultural, cell wall chemical, biochemical, physiological and molecular characteristics, as per the ISP (International Streptomyces Project) description. Light and scanning electron microscopic (SEM) views of the isolate showed spiral and smooth spore surface (Fig. 1). Characteristics of the isolate's colony on various culture media 


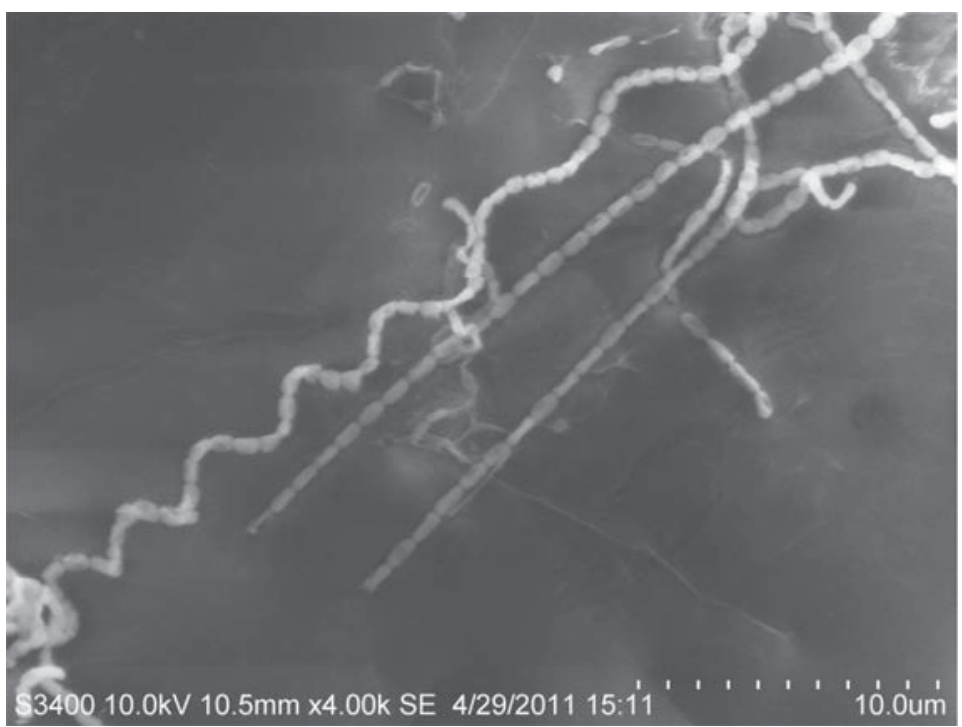

Figure 1. Morphology of Streptomyces parvulus DOSMB-D105

Table 1. Cultural characteristics of DOSMB-D105 on different media

\begin{tabular}{ccccc}
\hline \multirow{2}{*}{ Medium } & \multicolumn{4}{c}{ Properties of Streptomyces } \\
\cline { 2 - 4 } & Arial mycelium & Substrate mycelium & $\begin{array}{c}\text { Diffusible } \\
\text { pigment }\end{array}$ & $\begin{array}{c}\text { Melanin } \\
\text { pigment }\end{array}$ \\
\hline ISP2 & Grey & Yellow & Nil & Nil \\
ISP3 & Whitish grey & Dark yellow & Nil & Nil \\
ISP4 & Whitish grey & Dark yellow & Yellow & Nil \\
ISP5 & Grey & Yellow & Nil & Nil \\
ISP7 & Grey & Yellow & Nil & Positive \\
KUA & Grey & Yellow & Yellow & Nil \\
AIA & Grey & Yellow & Yellow & Nil \\
\hline
\end{tabular}

and physiological and biochemical characteristics are given in Tables I, II and III. The isolate showed the presence of LL-diaminopimelic acid and, glycine and did not contain any diagnostic sugar in its cell wall, identifying that the isolate DOSMB-D105 had type-I cell walls. 
Table II. Biochemical characteristics of DOSMB-D105

\begin{tabular}{rcc}
\hline S. No. & Test & DOSMB-D105 \\
\hline 1 & Indole production & - ve \\
2 & Methyl red & - ve \\
3 & Vogues-Proskauer & - ve \\
4 & Citrate utilization & $+\mathrm{ve}$ \\
5 & $\mathrm{H}_{2}$ S production & $-\mathrm{ve}$ \\
6 & Nitrate utilization & $-\mathrm{ve}$ \\
7 & Urease & $+\mathrm{ve}$ \\
8 & Catalase & $-\mathrm{ve}$ \\
9 & Oxidase & $-\mathrm{ve}$ \\
10 & Starch hydrolysis & $+\mathrm{ve}$ \\
11 & Gelatin hydrolysis & $-\mathrm{ve}$ \\
12 & Lipid hydrolysis & $-\mathrm{ve}$ \\
13 & Casein hydrolysis & $+\mathrm{ve}$ \\
14 & Lecithin hydrolysis & $+\mathrm{ve}$ \\
15 & Xanthine & $-\mathrm{ve}$ \\
16 & Testosterone & $-\mathrm{ve}$ \\
17 & Haemolysis & $-\mathrm{ve}$ \\
\hline
\end{tabular}

\section{Molecular characterization}

Sequence of the strain DOSMB-D105 was compared with the reference sequences of the NCBI database for pair wise alignment. It revealed that 827 base sequence of the strain DOSMB-D105 matched with Streptomyces parvulus (JQ638518) (Fig. 2). The secondary structure of 16S rRNA of S. parvulus DOSMB-D105 showed 33 stems. Free energy structure of the 16S rRNA secondary structure of the strain showed $193.3 \mathrm{kkal} / \mathrm{mol}$, as indicated by genebee software. The total restriction enzyme was $55, \mathrm{GC}$ content was $59 \%$ and -78.6 $\mathrm{kkal} / \mathrm{mol}$, as detected by NEB Cutter Program V 2.0. Based on the colony morphology, cell chemistry, biochemical, physiological and molecular characteristics, the strain DOSMB-D105 was identified as Streptomyces parvulus.

Antimicrobial efficacy of Streptomyces parvulus DOSMB-D105

The fermented broth of S. parvulus DOSMB-D105 was extracted by using five different solvents. Antimicrobial activity of the solvent extracts was tested against eleven pathogenic bacteria and six fungal pathogens. Maximum zone of inhibition of the ethyl acetate solvent extract was obtained against Pseudomonas sp. $(27.66 \mathrm{~mm})$, followed by Proteus sp. $(22.66 \mathrm{~mm})$, Bacillus sp. $(22.33 \mathrm{~mm})$, E. coli $(20.33 \mathrm{~mm})$, S. aureus $(22.33 \mathrm{~mm})$, L. lactis $(22.00 \mathrm{~mm})$, S. infantis (16.66 
Table III. Physiological characteristics of DOSMB-D105

\begin{tabular}{|c|c|c|}
\hline S. No. & Test & D105 \\
\hline 1. & \multicolumn{2}{|l|}{ Temperature } \\
\hline a. & 4 & - \\
\hline b. & 15 & - \\
\hline c. & 25 & + \\
\hline d. & 28 & + \\
\hline e. & 35 & + \\
\hline f. & 42 & + \\
\hline g. & 55 & - \\
\hline 2 & \multicolumn{2}{|l|}{$p H$} \\
\hline a. & 4 & - \\
\hline b. & 6 & + \\
\hline c. & 7 & + \\
\hline d. & 8 & + \\
\hline e. & 9 & + \\
\hline & 10 & - \\
\hline 3. & \multicolumn{2}{|l|}{ Antibiotic sensitivity (mm) } \\
\hline a. & Cephalothin (30 mcg) & $\mathrm{R}$ \\
\hline b. & Clindamycin (2 mcg) & 18 \\
\hline c. & Co-Trimoxazole $(25 \mathrm{mcg})$ & $\mathrm{R}$ \\
\hline d. & Erythromycin $(15 \mathrm{mcg})$ & $\mathrm{R}$ \\
\hline e. & Gentamycin $(10 \mathrm{mcg})$ & 21 \\
\hline f. & Oflaxin $(1 \mathrm{mcg})$ & $\mathrm{R}$ \\
\hline g. & Penicillin (10 unit) & $\mathrm{R}$ \\
\hline h. & Vancomycin (mcg) & $\mathrm{R}$ \\
\hline i. & Amikain & 35 \\
\hline 4 & \multicolumn{2}{|l|}{ Inhibitory compound $(\% \mathrm{w} / \mathrm{v})$} \\
\hline a. & Crystal violet $(0.0001)$ & + \\
\hline b. & Potassium tellurite $(0.001)$ & - \\
\hline c. & Sodium aside $(0.01)$ & + \\
\hline \multirow[t]{6}{*}{$\mathrm{d}$. } & Sodium chloride & \\
\hline & $1 \%$ & - \\
\hline & $3 \%$ & + \\
\hline & $5 \%$ & + \\
\hline & $7 \%$ & + \\
\hline & $10 \%$ & - \\
\hline 5 & \multicolumn{2}{|l|}{ Utilization of amino acids } \\
\hline a. & L-tyrosine & + \\
\hline b. & D-tryptophan & + \\
\hline c. & L-proline & + \\
\hline d. & L-methionine & + \\
\hline e. & L-lysine & + \\
\hline f. & L-arginice & + \\
\hline
\end{tabular}




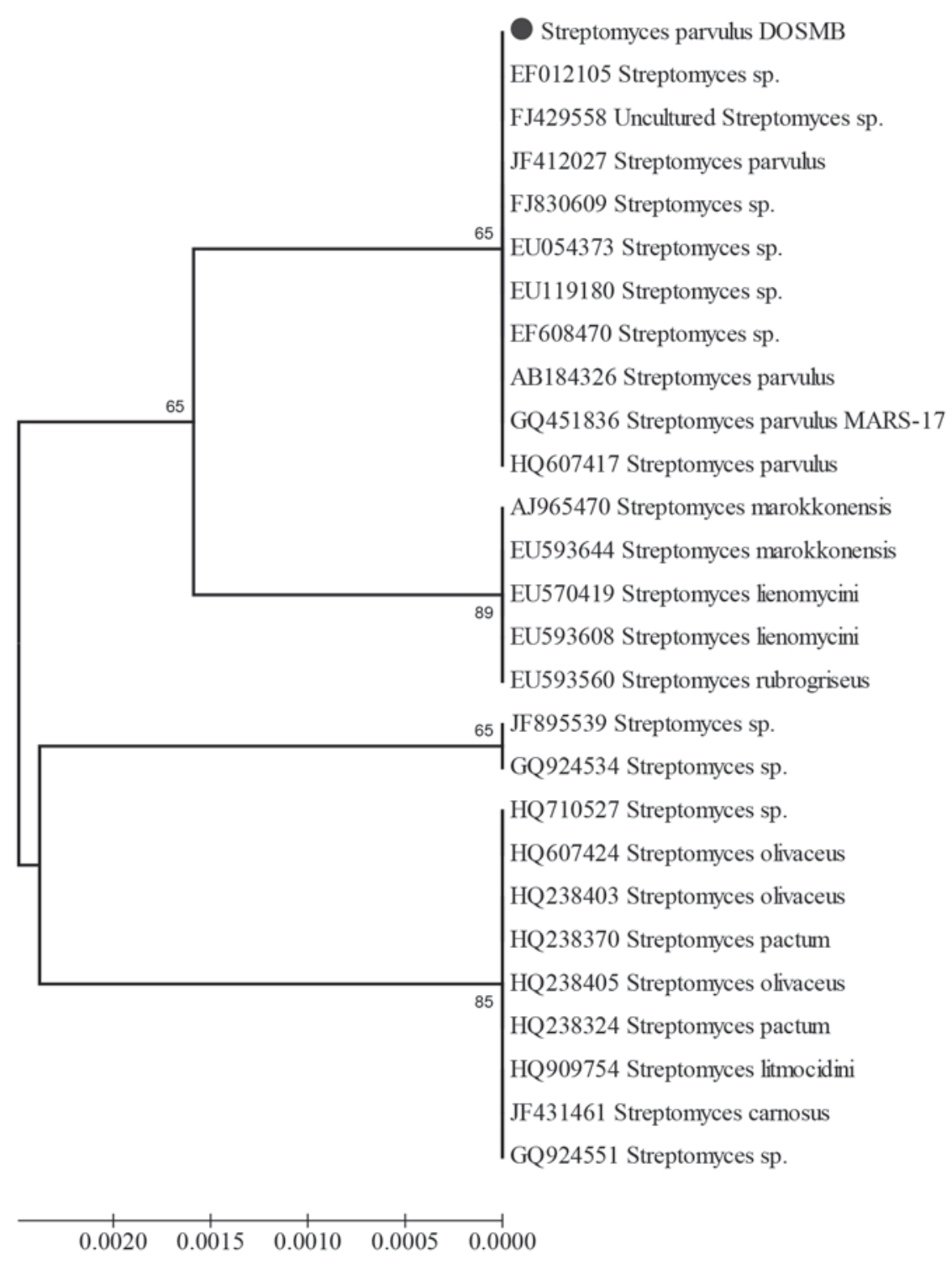

Figure 2. Phylogenetic tree of Streptomyces parvulus DOSMB-D105

$\mathrm{mm})$, K. pneumoniae $(15.66 \mathrm{~mm})$, V. cholarae $(15.33 \mathrm{~mm})$, C. diserus $(15.33 \mathrm{~mm})$, S. flexneri (13.33 mm), A. niger $(25.66 \mathrm{~mm})$, A. flavus $(20.33 \mathrm{~mm})$, A. fumigatus $(19.33 \mathrm{~mm})$, Penicillium sp. (18.66 mm), Fusarium sp. (17.33 mm) and C. magnolia $(20.66 \mathrm{~mm})$ (Plate 1 and Table IV). 

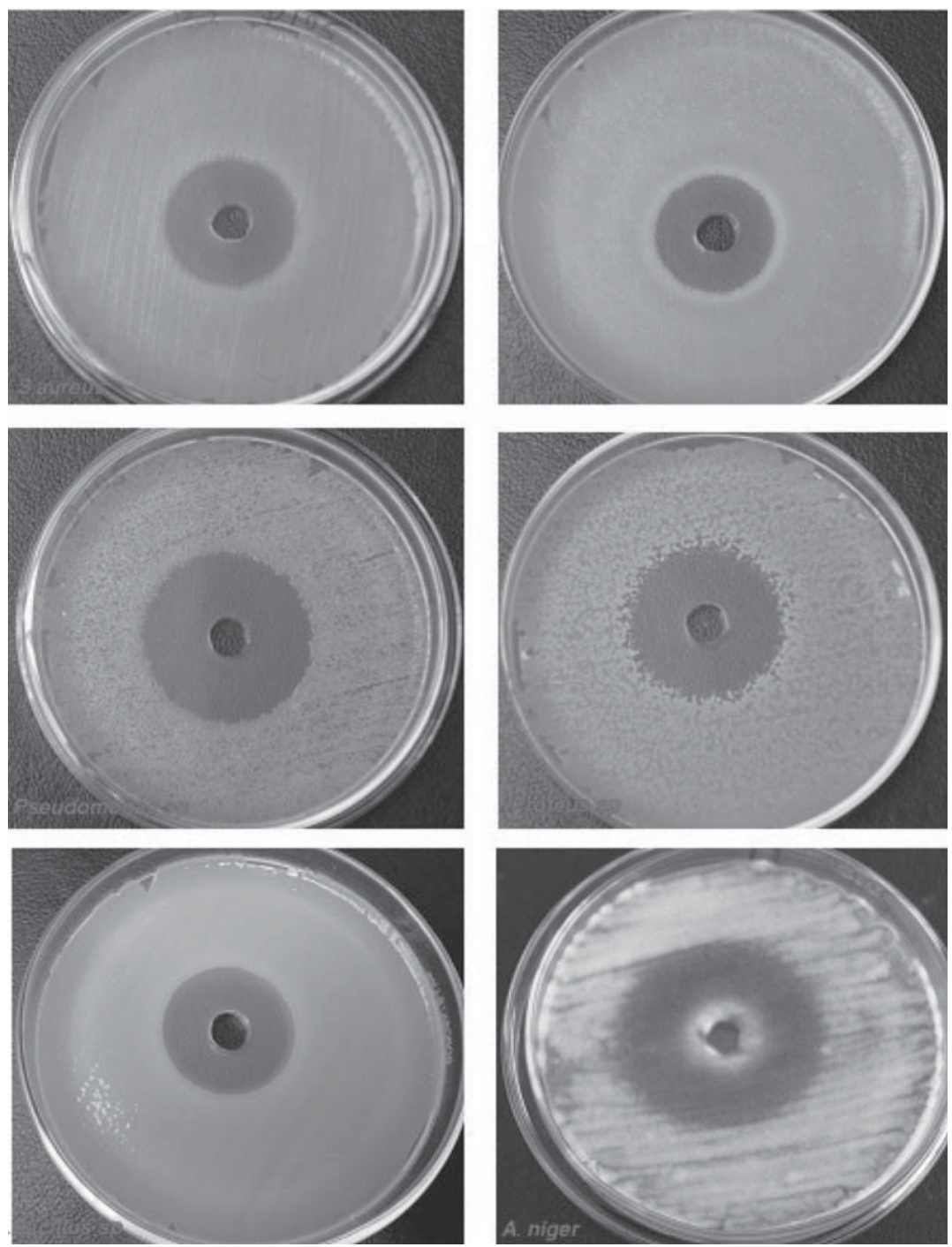

Plate 1. Antimicrobial activity of Streptomyces sp. DOSMB-D105

Maximum activity of chloroform extract was found against $S$. aureus $(20.66 \mathrm{~mm})$ followed by other tested pathogens and did not show any activity against $A$. niger and $A$. fumigatus. Methanol and alcohol extracts showed maximum activity against Bacillus sp. (17.66 $\mathrm{mm}$ and $16.33 \mathrm{~mm}$, respectively) and moderate to minimum activity against other pathogens. Methanol and alcohol extract did not express any zone of inhibition against $K$. pneumoniae, $S$. infantis, 
Table IV. Antimicrobial activity of S. parvulus DOSMB-D105 extracted by different solvents

\begin{tabular}{|c|c|c|c|c|c|c|c|}
\hline S. No & Pathogens & Methanol & Chloroform & Ethanol & $\begin{array}{c}\text { Ethyl } \\
\text { acetate }\end{array}$ & Hexane & $\begin{array}{l}\text { Control } \\
\text { DMSO }\end{array}$ \\
\hline 1 & K. pneumoniae & - & $13.33 \pm 0.50$ & - & $15.66 \pm 0.50$ & $12.66 \pm 0.19$ & $3.66 \pm 0.19$ \\
\hline 2 & S. infantis & - & $14.66 \pm 0.19$ & - & $16.66 \pm 0.38$ & $12.66 \pm 0.19$ & $3.33 \pm 0.38$ \\
\hline 3 & S. aureus & $13.33 \pm 0.38$ & $20.66 \pm 0.19$ & $14.33 \pm 0.19$ & $22.33 \pm 0.19$ & - & $5.66 \pm 0.19$ \\
\hline 4 & L. lactis & $17.0 \pm 0.33$ & $20.0 \pm 0.33$ & $14.66 \pm 0.19$ & $22.0 \pm 0.33$ & - & $7.0 \pm 0.33$ \\
\hline 5 & E. coli & $12.66 \pm 0.19$ & $18.66 \pm 0.19$ & $13.33 \pm 0.19$ & $20.33 \pm 0.19$ & - & $5.33 \pm 0.19$ \\
\hline 6 & V. cholerae & - & $9.66 \pm 0.19$ & - & $15.33 \pm 0.19$ & $9.66 \pm 0.19$ & $3.33 \pm 0.19$ \\
\hline 7 & S. flexheri & - & $8.33 \pm 0.19$ & - & $13.33 \pm 0.38$ & - & $3.33 \pm 0.19$ \\
\hline 8 & $\begin{array}{l}\text { Pseudomonas } \\
\text { sp. }\end{array}$ & - & $17.66 \pm 0.19$ & - & $27.66 \pm 0.19$ & - & $3.66 \pm 0.19$ \\
\hline 9 & Proteus sp. & $15.66 \pm 0.19$ & $20.66 \pm 0.19$ & $14.33 \pm 0.19$ & $22.66 \pm 0.19$ & $9.66 \pm 0.19$ & $2.33 \pm 0.19$ \\
\hline 10 & C. diserus & - & $12.33 \pm 0.19$ & - & $15.33 \pm 0.19$ & $11.66 \pm 0.19$ & $4.00 \pm 0.33$ \\
\hline 11 & Bacillus sp. & $17.66 \pm 0.19$ & $20.66 \pm 0.19$ & $16.33 \pm 0.19$ & $22.33 \pm 0.19$ & $15.33 \pm 0.19$ & $3.66 \pm 0.19$ \\
\hline 12 & A. niger & $23 \pm 0.33$ & - & $14.66 \pm 0.19$ & $25.66 \pm 0.19$ & $18.66 \pm 0.19$ & $3.33 \pm 0.19$ \\
\hline 13 & A. flavus & $18.66 \pm 0.19$ & $13.33 \pm 0.19$ & - & $20.33 \pm 0.19$ & $16 \pm 0.00$ & - \\
\hline 14 & A. fumigates & $16.33 \pm 0.38$ & - & $10.66 \pm 0.19$ & $19.33 \pm 0.19$ & $14.66 \pm 0.19$ & $3.66 \pm 0.19$ \\
\hline 15 & Penicillium sp. & $15.66 \pm 0.19$ & $13.0 \pm 0.33$ & $14.00 \pm 0.00$ & $18.66 \pm 0.19$ & $13.33 \pm 0.19$ & - \\
\hline 16 & Fusarium sp. & $14.33 \pm 0.38$ & $11.0 \pm 0.00$ & $11.66 \pm 0.19$ & $17.33 \pm 0.19$ & - & $3.00 \pm 0.00$ \\
\hline 17 & C. magnolia & $17.66 \pm 0.19$ & $12.66 \pm 0.19$ & $12.66 \pm 0.57$ & $20.66 \pm 0.19$ & $14.33 \pm 0.19$ & - \\
\hline
\end{tabular}

Mean values are present in the table (zone of inhibition $\mathrm{mm}$ )

V. cholerae, S. flexneri and C. diserus, and alcohol extract had no activity against Pseudomonas sp. and A. flavus. Hexane extract showed highest activity against A. niger $(18.66 \mathrm{~mm})$ followed by other tested pathogens; however, no activity was found against S. aureus, L. lactis, E. coli, S. flexneri, Pseudomonas sp. and Fusarium sp. (Table IV).

\section{Identification of compounds}

GC-MS spectral results and comparison of results with NIST library search productively enabled the presence of eight compounds in $S$. parvulus DOSMBD105: phenol, 2,4-bis(1,1-dimethylethyl); pyrrolo [1,2-a] pyrazine-1,4-dione, hexahydro-3-(2-metylpropyl); 7,8-epoxylanostan-11-ol, 3-acetoxy; dihydro-ergot- 
Table V. Compounds identified from the S. parvulus DOSMB-D105

\begin{tabular}{|c|c|c|c|c|c|c|}
\hline RT & Name of the compound & $\begin{array}{l}\text { Molecular } \\
\text { formula }\end{array}$ & MW & $\begin{array}{c}\text { Peak } \\
\text { area } \\
\%\end{array}$ & Nature & $\begin{array}{l}\text { Activity } \\
\text { (Ref. NIST) }\end{array}$ \\
\hline 7.94 & $\begin{array}{l}\text { Phenol, 2,4-bis } \\
\text { (1,1-dimethylethyl)- }\end{array}$ & $\mathrm{C}_{14} \mathrm{H}_{22} \mathrm{O}$ & 206 & 3.39 & $\begin{array}{l}\text { Phenolic } \\
\text { compound }\end{array}$ & $\begin{array}{l}\text { Antioxidant } \\
\text { Antimicrobial } \\
\text { Anti-inflammatory } \\
\text { Analgesic }\end{array}$ \\
\hline 11.57 & $\begin{array}{l}\text { Pyrrolo }[1,2-a] \\
\text { pyrazine-1,4-dione, } \\
\text { hexahydro-3- } \\
\text { (2-methylpropyl)- }\end{array}$ & $\mathrm{C}_{11} \mathrm{H}_{18} \mathrm{~N}_{2} \mathrm{O}_{2}$ & 210 & 10.32 & $\begin{array}{l}\text { Alkaloid } \\
\text { compound }\end{array}$ & $\begin{array}{l}\text { Antimicrobial } \\
\text { Anti-inflammatory }\end{array}$ \\
\hline 12.87 & $\begin{array}{l}\text { 7,8-Epoxylanostan-11-ol, } \\
\text { 3-acetoxy }\end{array}$ & $\mathrm{C}_{32} \mathrm{H}_{54} \mathrm{O}_{4}$ & 502 & 24.81 & Steroid & $\begin{array}{l}\text { Antimicrobial } \\
\text { Anti-inflammatory } \\
\text { Anti-arthritic } \\
\text { Antiasthma } \\
\text { Anticancer }\end{array}$ \\
\hline 18.80 & $\begin{array}{l}\text { Dihydroergotamine } \\
\text { Mesylate }\end{array}$ & $\mathrm{C}_{33} \mathrm{H}_{37} \mathrm{~N}_{5} \mathrm{O}_{5}$ & 583 & 14.95 & $\begin{array}{l}\text { Alkaloid } \\
\text { compound }\end{array}$ & $\begin{array}{l}\text { Antimicrobial } \\
\text { Anti-inflammatory }\end{array}$ \\
\hline 20.72 & $\begin{array}{l}\text { 1,2-Benzenedicarboxylic } \\
\text { acid, diisooctyl ester }\end{array}$ & $\mathrm{C}_{24} \mathrm{H}_{38} \mathrm{O}_{4}$ & 390 & 34.51 & $\begin{array}{l}\text { Plasticizer } \\
\text { compound }\end{array}$ & $\begin{array}{l}\text { Antimicrobial, } \\
\text { Anti fouling }\end{array}$ \\
\hline 25.09 & $\begin{array}{l}\text { Phthalic acid, } \\
\text { diisodecyl ester }\end{array}$ & $\mathrm{C}_{28} \mathrm{H}_{46} \mathrm{O}_{4}$ & 446 & 5.08 & $\begin{array}{l}\text { Plasticizer } \\
\text { compound }\end{array}$ & $\begin{array}{l}\text { Antimicrobial } \\
\text { Anti fouling }\end{array}$ \\
\hline 26.69 & $\begin{array}{l}\text { Octadecane, } \\
\text { 3-ethyl-5-(2-ethylbutyl)- }\end{array}$ & $\mathrm{C}_{26} \mathrm{H}_{54}$ & 366 & 4.16 & $\begin{array}{l}\text { Alkane } \\
\text { compound }\end{array}$ & $\begin{array}{l}\text { No activity } \\
\text { reported }\end{array}$ \\
\hline 34.48 & Ethyl iso-allocholate & $\mathrm{C}_{26} \mathrm{H}_{44} \mathrm{O}_{5}$ & 436 & 2.77 & Steroid & $\begin{array}{l}\text { Same like } 3^{\text {rd }} \\
\text { compound }\end{array}$ \\
\hline
\end{tabular}

amin-emesylate; 1,2-benzenedicarboxylic acid, diisooctyl ester; phthalic acid, diisodecyl ester; octadecane, 3-ethyl-5-(2-ethylbutyl)and ethyl iso-allocholate. Among these, seven compounds were bioactive compounds except Octadecane, 3-ethyl-5-(2-ethylbutyl). Mass spectrum and structures of all the compounds (Fig. 3 and 4) and the details of the identified compounds are given in Table V.

\section{Discussion}

Identification of strain DSMB-A107

Smooth surfaced spores are characteristic of 75 to $80 \%$ of the Streptomyces [19-20]. When the strain DOSMB-D105 was examined under the SEM, it 


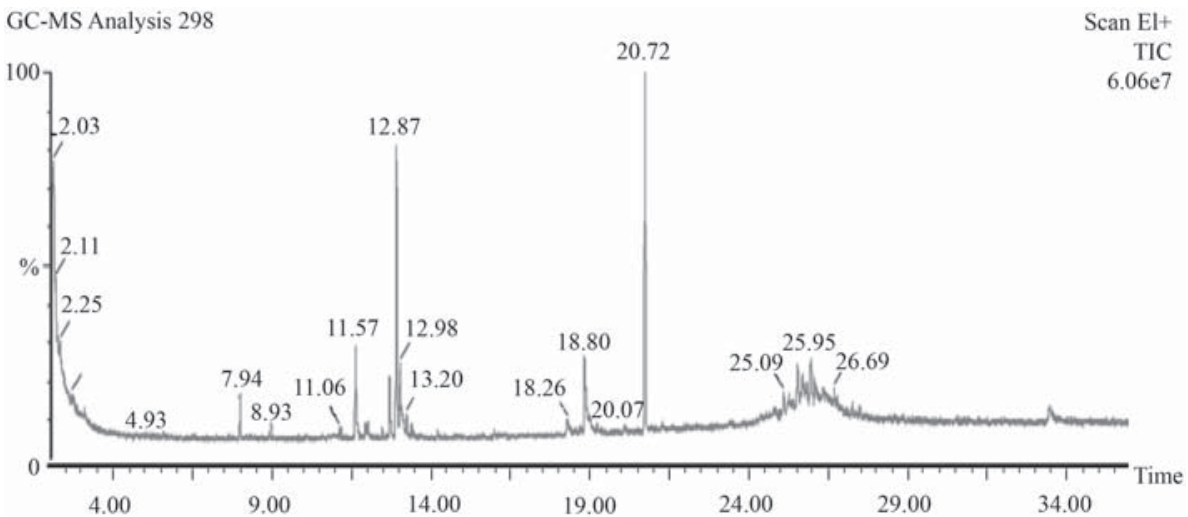

Figure 3. Chromatogram of Streptomyces parvulus DOSMB-D105 by GC-MS

showed spiral and smooth spore surface. Chemical composition of the medium has a bearing on the morphology of the organisms. The strain DOSMB-D105 was grown on various media, viz. ISP2, ISP3, ISP4, ISP5, ISP7, KUA and AIA. Of the different media used, Kuster's agar medium gave better result than the others as the strain DOSMB-D105 could easily utilize all the nutrients and sporulate in this medium. Similar types of observations have been made by many workers [21-22].

\section{Cell wall chemistry}

Simple quantitative analysis of cell wall amino acid is one of the most useful techniques for the primary identification of actinobacteria at the genus level. The most useful diagnostic marker is the diaminopimelic acid which occupies the anchor position in the tetrapeptide of the cell wall peptidoglycan, since many actinobacteria contain meso-diaminopimelic acid. Of the various sugars occurring in the cell hydrolysate of actinobacteria, four sugars, arabinose, galactose, madurose and xylose are of taxonomic importance. Members of the family Streptomycetaceae do not contain any of these sugars and in most cases they are devoid of any other carbohydrates. The cell wall chemistry of the Streptomyces spp. has also been reported by several researchers [23-24]. In the present study, $S$. parvulus DOSMB-D105 was investigated for the cell wall amino acids and whole cell sugars. It showed the presence of LL-diaminopimelic acid and glycine and did not contain any diagnostic sugars in the cell wall. 


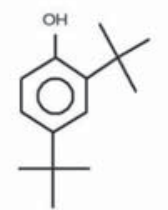

Phenol, 2,4-bis (1,1-dimethylethyl)-<smiles></smiles>

7,8-Epoxylanostan-11-ol, 3-acetoxy-<smiles>CCCCCCOC(=O)c1ccccc1C(=O)OCCCCCCCCCCC(C)(C)CC</smiles>

1,2-Benzenedicarboxylic acid, diisodecyl ester<smiles>CCCCCCCCCCCCCC(CC)CC(CC)CC</smiles>

Octadecane, 3-ethyl-5-(2-ethylbutyl)<smiles>C=C1NC(CC(C)C)C(=O)N2CCCC12</smiles>

Pyrrolo [1,2-a] pyrazine-1,4-dione, hexahydro-3-(2-methylpropyl)

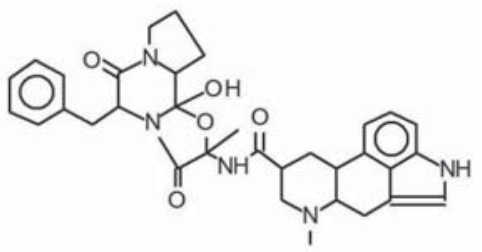

Dihydroergotamine Mesylate<smiles>C=C(CCCCCC)C1CCCCC1C(=C)CCCCCCCCCC(C)C</smiles>

Phthalic acid, diisodecyl ester<smiles>CCOC(=O)CCC(C)C1CCC2C3C(O)CC4CC(O)CCC4(C)C3CC(O)C12C</smiles>

Ethyl iso-allocholate

Figure 4. Structure of identified compounds of Streptomyces parvulus DSMB-D105

\section{Biochemical characterization}

Various biochemical characterizations of Streptomyces spp. were used for their identification [25]. In the present investigation, it was found that $S$. parvulus-DOSMB-D105 had nitrate reducing ability, as referred by others [26]. 
Production of urease, catalase, oxidase, $\beta$-lactamase and citrase are important for characterizing the Streptomyces species [27]. In the present study, it was found that $S$. parvulus DOSMB-D105 produced urease and citrase and did not produce catalase. Similarly, hydrolyse of starch, gelatin, casein, lecithin, xanthine and haemolysis as also used for characterizing the isolates. In the present study, DOSMB-D105 was found to hydrolyse starch, lecithin and casein and the isolate was not able to hydrolyse testosterone, lipid and gelatine.

Physiological characteristics of S. parvulus DOSMB-D105.

Physiological properties are very important for the identification of Streptomyces; however, they are not much of significance in the identification up to species level but they are used as markers. Strains can be recognized for various physico-chemical properties, influencing the growth of Streptomyces [28]. Present investigation revealed that the optimum $\mathrm{pH}$ was 6-9 and temperature was $25-42{ }^{\circ} \mathrm{C}$, for the growth of $S$. parvulus DOSMB-D105. Growth response of the organism to the inhibitory compounds was studied and it was found that the isolate could tolerate crystal violet, sodium aside and sodium chloride. Likewise, other researchers have reported the tolerance of actinobacteria to inhibitory compounds [24, 29]. S. parvulus DOSMB-D105 was sensitive to gentamycin, clindamycin and amikacin and resistant to cepholothin, co-trimoxale, oflaxin and penicillin as observedin Streptomyces spp. by Gesheva and Gesheva [23]. Various carbon source utilization ability confirmed the identity of Streptomyces spp. [24]. The isolate DOSMB-D105 was able to utilize dextrose, cellulose, xylose, arabinose, raffinose, mannitol, fructose, sorbitol, maltose, lactose, rhamnose, adonital and starch. But, it did not utilize inositol and L-rhamose. Thus, the present investigation could find that the physiological characteristics of S. parvulus DOSMBD105 varied depending on the nutritive and the physical conditions.

\section{Molecular taxonomy of S. parvulus DOSMB-D105}

DNA based molecular methods have been used for species differentiation and the identification of actinobacteria. The strain DOSMB-D105 was similar (100\%) to that of S. parvulus (EF012105) isolated from the mangrove soil of China and S. parvulus (GQ451836), from the soil of Bangladesh, and K2P value of DOSMB-D105 was also similar to that of S. parvulus (EF012105). This is providing with the message for the geographical relationship of the microorganisms, their distribution and environmental tolerance. 
Phylogenetic studies based on 16S rDNA sequences would enhance the knowledge on the systematics of actinobacteria [31]. Sequences of 16S rDNA have provided actinobacteriologists with phylogenetic trees that allow the investigation of evolution of actinobacteria and also provide the basis for identification. In the present study, secondary structure of $16 \mathrm{~S}$ rDNA gene consisted of 33 stems and it showed energy threshold, cluster factor, conserved factor, compensated factor, conservativity, start position, end position, part of sequence greedy parameter and treated sequence. The free energy structure of the $16 \mathrm{~S} \mathrm{rDNA} \mathrm{sec-}$ ondary structure of the strain DOSMB-D105 (JQ638518) was $193.3 \mathrm{kal} / \mathrm{mol}$. The total restriction enzymes $48 \%$ and the GC content was $59 \%$ and the free energy structure was $-78.6 \mathrm{kal} / \mathrm{mol}$. Distinct variation in the secondary structure, $\mathrm{G}+\mathrm{C}$ composition and presence of restriction enzymes sites in 16S rDNA sequence of the strain DOSMB-D105 showed molecular level specificity of each and every individual isolates. Apparent phylogenetic relationships, secondary structure and restriction enzyme sites in 16S rDNA have been reported by many workers [32-34]. Based on the morphological, cell wall chemistry and molecular properties of the strain DOSMB-D105, it was identified as Sparvulus. DOSMBD105 (JQ638518). The identity of the isolate was also confirmed with Bergey's Manual of Systematic Bacteriology [35], Bergey's Manual of Determinative Bacteriology [36] and phylogenetic analysis using sequence alignment program CLUSTAL W [37].

\section{Antimicrobial efficacy of crude extract}

Antimicrobial efficacy of S.parvulus DOSMB-D105 was tested against eleven pathogenic bacteria and six fungi with five different solvent extracts. The maximum antimicrobial efficacy of the ethyl acetate solvent extract of the isolate was found against the following pathogens: Pseudomonas sp., A. niger, Proteus sp., Bacillus sp. and S. aureus, C. magnolia, E. coli and A. flavus, L. lactis, A. fumigatus, Penicillium sp., Fusarium sp., S. infantis, K. pneumoniae, V. cholerae, C. diserus and $S$. flexneri.

Out of five different solvents used to extract the antimicrobial compounds of DOSMB-D105, ethyl acetate solvent extract only showed remarkable activity against all the pathogens tested. Whereas the methanol, chloroform, ethanol and hexane extracts showed moderate to minimum activity and they did not show activity against all the pathogens tested. This finding leads support to that of Vijayakumar et al. [38] who reported that the antimicrobial activity of different solvent extracts of the isolate Streptomyces sp. (VPTSA18) against 13 pathogens (11 species of bacteria and 2 species of fungi) was remarkable. The ethyl acetate- 
treated compound (extract) was highly active against bacterial and fungal pathogens and the other solvent extracts had only moderate to minimum inhibitory effect. Also, Pugazhvendan et al. [39] reported that the ethyl acetate extract of Streptomyces showed the maximum inhibition range of 6-15 $\mathrm{mm}$ against bacterial pathogens. Likewise, many researchers have evaluated the antimicrobial efficacies of the actinobacteria using various solvents including n-butanol [40], chloroform [41], ethyl acetate and methanol [42], ethyl acetate, methanol, chloroform and alcohol [43], petroleum ether [44], $n$-butanol and ethyl acetate [45]. It was found that the ethyl acetate solvent extract had promising activity against most of the pathogens tested. Similar findings have also been reported by many researchers [46-47]. Thus, the present and previous studies have indicated that the ethyl acetate is a suitable solvent for the extraction of the antimicrobial compounds from the marine actinobacteria.

\section{Identification of bioactive compounds}

Antimicrobial compounds present in the cell free ethyl acetate extract of S. parvulus DOSMB-D105 were identified by GC-MS analysis. The active principles with their retention time (RT), molecular formula, molecular weight (MW) and concentration (\%) in the ethyl acetate extract of S. parvulus DOSMBD105 were noted. Totally, eight compounds phenol, 2,4-bis(1,1-dimethylethyl); pyrrolo [1,2-a] pyrazine-1,4-dione, hexahydro-3-(2-metylpropyl); 7,8-epoxylanostan-11-ol, 3-acetoxy; dihydroergotamine mesylate; 1,2-benzenedicarboxylic acid, diisooctyl ester; phthalic acid, diisodecyl ester; octadecane, 3-ethyl-5-(2ethylbutyl) and ethyl iso-allocholate were identified from the ethyl acetate extract of S. parvulus DOSMB-D105 as shown by NIST library. Previously, only a few bioactive compounds which are currently in use such as actinomycin D and manumycin A [48-50] have been reported from S. parvulus. Similarly, Livia and Avira [51] have reported different antimicrobial, antiviral, anticancer and antimalarial compounds from the marine S. parvulus.

\section{Conclusion}

As a conclusion of the present study we can state that the marine S. parvulus DOSMB-D105 is a good source for obtaining novel bioactive compounds for use as biomedicines. Identification of the bioactive compounds in S. parvulus DOSMB-D105 is a significant finding and it can pave way for the large scale production of antibiotics, when pursued in further. 


\section{Acknowledgements}

Authors are thankful to the Central Instrumentation Facility section (CIF) of the Pondicherry University for SEM facilities. They also thank Prof. L. Kannan, Former VC, Thiruvalluvar University, Vellore for guiding through the manuscript and offers suggestions. R Baskaran expresses his profound thanks to Prof. David A Hopwood, John Innes Centre, England for having providedwith the practical Streptomyces genetics book. He also thanks to University Grants Commission (UGC) for providing with a Research Fellowship in Science to Meritorious Student (RFSMS).

\section{Conflict of Interest}

The authors declare that there is no conflict of interests regarding the publication of this paper.

\section{References}

1. Faulkner, D. J.: Marine natural products. Nat Prod Rep 17, 7-55 (2000).

2. Hentschel, U., Usher, K. M., Taylor, M. W.: Marine sponges as microbial fermenters. Fems microbial Ecol 55, 167-177 (2006).

3. Vijayakumar, R., Muthukumar, C., Thajudin, N., Panneerselvam, A., Saravanamuthu, R.: Studies on the diversity of actinomycetes in the palkstait region of Bay of Bangal, India. Actinomycetologica 21, 59-65 (2007).

4. Sivakuamr, K., Maloy Kumar Sahu., Manivel, P. M., Kanna, L.: Optimum conditions for L-glutaminase production by actinomycete strain isolated from estuarine fish Chanos chanos (Forskal, 1775). Ind J of Exp Biol 44, 256-258 (2006).

5. Newman, D. J., Cragg, M. G.: Natural products as sources of new drugs over the last 25 years. J Nat Prod 70, 461-477 (2007).

6. Findlay, R. H., Fell, J. W., Colemanm, N. K., Vestal, J. R.: Biochemical indicators of the role of fungi and thraustochytrids in mangrove detrital systems. In: Moss S. T. (ed) The biology of marine fungi. Cambridge University Press, Cambridge, pp. 91-104 (1986).

7. Kampfer, P.: The Family Streptomycetaceae, Part I: Taxonomy. Dworkin, M. et al. (eds.) The prokaryotes: a handbook on the biology of bacteria. Berlin: Springer 538-604 (2006).

8. Meienhofer, J., Atherton, E.: Structure activity relationship in the actinomycins. Adv Appl Microbiol 16, 203-300 (1973).

9. Berdy, J.: Recent advances in and prospects of antibiotic research. Proc Biochem 15, 28-35 (1980).

10. Baskaran, R., Vijayakumar, R., Mohan, P. M.: Enrichment method for the isolation of bioactive actinomycetes from mangrove sediments of Andaman Island, India. Malaysian $\mathrm{J}$ of Microbio 7, 22-28 (2011). 
11. Shirling, E. B., Gottlieb, D.: Methods for characterization of Streptomyces species. Int J of Syst Bact 16, 312-340 (1966).

12. Das, S., Lyla, P. S., Khan, S. A.: Characterization and identification of marine actinomycetes existing systems, complexities and future directions. Natl Acad Sci Let 31, 149-160 (2008).

13. Becker, B., Lechevalier, M. P., Lechevalier, H. A.: Chemical composition of cell wall preparations from strains of various form genera of aerobic actinomycetes. Appl Microbiol 13, 236-243 (1965).

14. Lechevalier, M. P., Lechevalier, H. A.: Chemical composition as a criterion in the classification of aerobic actinomycetes. Int J Syst Bacteriol 20, 435-443 (1970).

15. Wilson, K. F. A., Brent, R.: Preparation of genomic DNA from bacteria. In: Current Protocol in Molecular Biology (Ausubel Kingstan, R. E., Moore, D. D., Smith, J. A., Seidman, J. G. and Struhl, K., eds.), Chapter 2-4, Greene publishing and Wiley Inter science, New York (1990).

16. Weisburg, W. G., Barns, S. M., Pelletier, D. A., Lane, D. J.: 16S rDNA amplification for phylogenetic study. J Bacteriol 173, 697-703 (1991).

17. Kumar, S. K., Tamura, I. B., Jakobsen, Nei, M.: MEGA2: molecular evolutionary genetics analysis software. Bioinfor 17, 244-245 (2001).

18. Sambamurthy, K., Ellaiah, P.: A new Streptomycete producing neomycin (B and C) complex S. marinensis (Part-I). Hind. Antibiot Bull 17, 24-28 (1974).

19. Tresner, H. D., Backus, E. J., Davies, M. C.: Electron microscopy of Streptomyces spore morphology and its role in species differentiation. J Biotechnol 81, 70-80 (1961).

20. Atalan, E., Manfio, G. P., Ward, A. C., Kroppenstedt, R. M., Goodfellow, M.: Biosystematic studies on novel streptomycetes from soil. Antonie Van Leeuwenhoek 77, 337-353 (2000).

21. Shinobu, R.: Physiological and cultural study for the identification of soil actinomycetes species. Mem Osaka Univ Bot Nat Sci 7, 1-76 (1958).

22. Porter, J. N., Wilhelm, J. J., Simpson, R. B.: Useful criteria for studying the distribution of Streptomyces in soils. In Developments in Industrial Microbiology, III. Plenum press, Inc., New York, pp. 240-244 (1961).

23. Gesheva, V., Gesheva, R.: Structure of the population of Streptomyces hygrocopicus and characteristics of its variants. Actinomycetes 4, 65-71 (1993).

24. Bernan, V. S., Montenegro, D. A., Korshalla, J. D., Maieses, W. M.: Steinberg D. A., Greenstein M. Bioxalomycins, new antibiotics produced by the marine Streptomyces sp. LL-31F508: taxonomy and fermentation. J Atibiot 47, 1417-1424 (1994).

25. Chun, J., Youn, H. D., Yim, H. I., Lee, H., Kim Yung Chil Hah., M. Y., Kang, S.: Streptomyces seouulensis sp. nov. Int J Sys Bscteriol 47, 240-245 (1997).

26. Kuster, E.: Morphological and physiological aspects of the taxonomy of streptomycetes. Microbiol Espanola 16, 193-202 (1963).

27. Gottlieb, D.: An evaluation of criteria and procedures used in the description and characterization of the streptomycetes. Appl Microbiol 9, 55-65 (1961).

28. Ocallaghan, C., Morris, A., Kirby, S. M., Shingler, A. H.: Novel methods for detection of $\beta$-lactamase by using a chromogenic cephalosporin substrate. Antimicro Agents Chemothe 1, 283-288 (1972).

29. Chakraborthy, D., Mondal, B., Pal, S. C., Sen, S. K.: Characterization and identification of broad spectrum antibiotic producing Streptomyces hygroscopicus D1.5. Hindustan Antibiot Bull 37, 37-43 (1995). 
30. Tresner, H. D., Hayes, J. A., Bakus, E. J.: Differential tolerance of streptomycetes to sodium chloride as a taxonomic aid. Appl Microbiol 16, 1134-1136 (1968).

31. Yokota, A.: Phylogenetic relationship of actinomycetes. Atlas of actinomycetes, Asakura Publishing Co Ltd., Japan, pp. 194-297 (1997).

32. Cook, A. E., Meyers, P. R.: Rapid identification of filamentous actinomycetes to the genus level using genus specific 16S RNA gene restriction fragment pattern. Int J Syst Micobiol 53, 1907-1915 (2003).

33. Kim, B. S., Kim, C. J., Chun, J., Koh, Y. H., Lee, S. H., Hyun, J. W., Cha, C. Y., Kook, Y. H.: Phylogenetic analysis of the genera Streptomyces and Kitasatospora based on partial RNA polymerase $\beta$-subunit gene (rpo B) sequences. Int J Syst Evol Microbiol 54, 593-598 (2004).

34. Dhanasekaran, D.: Biochemical, molecular characterization and antimicrobial compounds of Streptomyces spp. from Cuddalore district, Tamil Nadu, India. Ph.D., Thesis, Bharathidasan University, India, p. 66 (2005).

35. Williams, S. T., Sharpe, M. E., Holt, J. G.: Streptomycetes and related genera in Bergey's Manual od Systematic Bacteriology Vol 4, Williams and Wilkins, U.S.A. 2463-2469 (1989).

36. Pridham, T. G., Tresner, H. D.: Streptomycetaceae. In Bergey's Manual of Determinative Bacteriology ( $8^{\text {th }}$ Edition), The Williams and Wilkins Co., Baltimore, U.S.A. p. 747 (1974).

37. Higgins, D. G., Bleasbym, A. T., Fuchs, R., Clustal, V.: Improved software for multiple sequence alignment. CABIOS 8, 189-191 (1992).

38. Vijayakumar, R., Panneerselvam, K., Muthukumar, C., Thajuddin, N., Panneerselvam, A., Saravanamuthu, R.: Optimization of antimicrobial production by a marine actinomycete Streptomyces afghaniensis VPTS3-1 isolated from Palk Strait, East Coast of India. Indi J 52(2): 230-239 (2012). DOI: 10.1007/s12088-011-0138-x

39. Pugazhvendan, S. R., Kumaran, S., Alagappan, K. M., Prasad, G.: Inhibition of fish bacteriology pathogens by antagonistic marine actinomycetes. Euro J of App Sci 2, 41-43 (2010).

40. Sahin, N., Ugur, A.: Investigation of the antimicrobial activity of some isolates. Turk $\mathbf{J}$ Biol 27, 79-84 (2003).

41. Thangadurai, D., Murthy, K. S. R., Prased, P. J. N., Pullaiah, T.: Antimicrobial screening of Decalepis hamiltonii Wight and Arn. (Asclepiadaceae) root extracts against food-related microorganisms. J Food Safety 24, 239-245 (2004).

42. Taechowisan, T., Lu, C., Shen, Y., Lumyong, S.: 4-Arylcomarins from endophytic Streptomyces aureofaciens CMUAc130 and their antifungal activity. Annals of Microbil 55, 63-66 (2005).

43. Remya, M., Vijayakumar, R.: Isolation and characterization of marine antagonistic actinomycetes from west coast of India. Medi and Boil 15, 13-19 (2008).

44. Vimal, V., Mercy, R. B., Kannabiran, K.: Antimicrobial activity of marine actinomycete, Nocardiopsis sp. VITSVK5 (FJ973467). Asia J Med Sci 1, 57-63 (2009).

45. Usha, R., Ananthavalli, P., Venil, G. K., Palaniswamy, M.: Antimicrobial and antiangiogenesis activity of Streptomyces parvulus KUAP106 from mangrove soil. Euro J of Biol Sci 2, 77-83 (2010).

46. Saadoun, I., Al-Momani, F.: Activity of North Jordan streptomycete isolates against Candida albicans. World J Microbiol Biotech 16, 139-142 (2000).

47. Balagurunathan, R., Subramanian, A.: Antagonistic Streptomyces from marine sediments. Adv Bioscie 20, 71-76 (2001). 
48. Williams, E. K.: Development of a chemically defined medium for the synthesis of actinomycin D by Streptomyces parvulus. Antimic Agents and Chemo 11, 281-290 (1977).

49. Inbar, L., Lapidot, A.: 13C Nuclear Magnetic Resonance and Gas Chromatography-Mass Spectrometry Studies of Carbon Metabolism in the Actinomycin D Producer Streptomyces parvulus by use of 13C-Labeled Precursors. J of Bacteriol 173, 7790-7801 (1991).

50. Sousa, M. F. V. Q., Lopes, C. E., Júnior, N. P. A.: Chemically defined medium for production of actinomycin D by Streptomyces parvulus. Brazi Arch of Biol and Tech 44, 227 231 (2001).

51. Livia, I., Avira, L.: The structure and biosynthesis of new Tetrahydropyrmidine derivatives in actinomycin D producer Streptomyces parvulus. American Society for Biochemistry and Molecular Biology 263, 16014-16022 (1988). 